\title{
Major geological events in the Late Guadalupian and carbon-strontium isotope responses in the Yangtze platform, South China
}

\begin{tabular}{|c|c|}
\hline Journal: & Canadian Journal of Earth Sciences \\
\hline Manuscript ID & cjes-2017-0103.R1 \\
\hline Manuscript Type: & Article \\
\hline Date Submitted by the Author: & 24-Jul-2017 \\
\hline Complete List of Authors: & $\begin{array}{l}\text { Shi, Zejin; Chengdu University of Technology, State Key Laboratory of Oil } \\
\text { and Gas Reservoir Geology and Exploitation; Chengdu University of } \\
\text { Technology, College of Energy Resources } \\
\text { Yin, Guan; Chengdu University of Technology, College of Earth Sciences } \\
\text { Li, Wenjie; Chengdu University of Technology, College of Energy Resources } \\
\text { Yang, Huaixin; Chengdu University of Technology, College of Energy } \\
\text { Resources } \\
\text { Zhang, Jin; Chengdu University of Technology, College of Energy } \\
\text { Resources } \\
\text { Lu, Leixun; Chengdu University of Technology, College of Energy Resources } \\
\text { Tian, Yaming; Chengdu University of Technology, College of Earth Sciences } \\
\text { Wang, Yong; Chengdu University of Technology, College of Earth Sciences }\end{array}$ \\
\hline $\begin{array}{r}\text { Is the invited manuscript for } \\
\text { consideration in a Special } \\
\text { Issue? : }\end{array}$ & N/A \\
\hline Keyword: & $\begin{array}{l}\text { regression, volcanism, biodiversity crisis, carbon-strontium, late } \\
\text { Guadalupian }\end{array}$ \\
\hline
\end{tabular}




\section{Major geological events in the Late Guadalupian and carbon-strontium}

2 isotope responses in the Yangtze platform, South China

3 Zejin Shi ${ }^{\mathrm{a}, \mathrm{b}, *}$, Guan Yin ${ }^{\mathrm{c}}$, Wenjie $\mathrm{Li}^{\mathrm{b}}$, Huaixin Yang ${ }^{\mathrm{b}}$, Jin Zhang ${ }^{\mathrm{b}}$, Leixun $\mathrm{Lu}^{\mathrm{b}}$, Yaming Tian

$4 \quad$, Yong Wang ${ }^{\mathrm{c}}$

$5 \quad$ a State Key Laboratory of Oil and Gas Reservoir Geology and Exploitation, Chengdu

6 University of Technology, Chengdu 610059, China

$7 \quad$ b College of Energy Resources, Chengdu University of Technology, Chengdu 610059, China

$8 \quad{ }^{c}$ College of Earth Sciences, Chengdu University of Technology, Chengdu 610059, China

$9 \quad{ }^{*}$ Corresponding author: Zejin Shi, E-mail: zejin_shi@hotmail.com 


\section{Abstract}

12 Two sections of marine carbonate strata, Podu and Lengshuixi, from the Yangtze 13 platform, South China, are investigated in terms of major geological events and 14 carbon-strontium isotope responses. The results show a large-scale regression and a Large 15 Igneous Province (LIP) event occurred in succession in the short interval of the late 16 Guadalupian, inducing a biodiversity crisis. The regression event, marked by an increase in

17 the ${ }^{87} \mathrm{Sr} /{ }^{86} \mathrm{Sr}$ ratio, is observed in the Jinogondolella postserrata Zone. It contributed 18 significantly to the reduction in species habitat, leading to notable losses within the shallow 19 water species assemblage. A subsequent LIP event occurred after the appearance of 20 Jinogondolella altudaensis, releasing $\mathrm{CO}_{2}$ and numerous other deleterious gases that further 21 amplified the crisis in shallow water to deep sea environments. The corresponding decline in $22 \mathrm{Sr}$ and $\mathrm{C}$ isotopes could have been a response to the basaltic eruption (relative increase from 23 mantle-derived $\mathrm{Sr}$ ) and release of ${ }^{12} \mathrm{C}$-enriched $\mathrm{CO}_{2}$. During the process of creation of the LIP, 24 the decline in $\delta^{13} \mathrm{C}_{\text {carb }}$ was mainly associated with ${ }^{12} \mathrm{C}$-enriched $\mathrm{CO}_{2}$ release from organic matter in sedimentary strata, and high temperature isotope fractionation during the volcanic eruption stage (exceeding $1200{ }^{\circ} \mathrm{C}$ ). This study could further provide valuable clues regarding development process on the major geological events and the causes of the biodiversity crisis. 


\section{Introduction}

The late Permian is an important period in Earth's history. Large-scale geotectonic activity, Large Igneous Province (LIP) events, and mass extinctions were concentrated within a short interval of less than 10 Myr. Although there has been a lot of research into these events, the biodiversity crisis in the late Guadalupian, as a prelude to the end-Permian mass extinction event, still attracts significant attention. The crisis was mainly restricted to tropical invertebrate taxa with passive respiratory systems such as corals, bryozoans, brachiopods, and ammonoids (Weidlich 2002; Wignall et al. 2009a).

In the Laibin sections of the Yangtze platform, South China (Global Stratotype Section and Point (GSSP)), Mei et al. (1998) placed the biodiversity crisis approximately $2 \mathrm{~m}$ below the top of the Laibin Limestone Member. Jin et al. (2006) placed the mass extinction around the base of the L. minima Zone, because most keriotheca-walled fusulinaceans (major victims of the extinction event) disappeared close to this level. These conclusions may be similar to that of Texan, West Texas (Yang and Yancey 2000; Wignall et al. 2009a), and have been accepted by most researchers.

Moreover, the negative $\mathrm{C}$ isotope excursion, a mark of the biodiversity crisis, occurred in various patterns (Shen et al. 2013). A large negative carbon isotope excursion (ca. 6\%o from the Xiongjiachang section in Guizhou) was reported (Wignall et al. 2009b, 2012; Bond et al. 2010), but not confirmed, in the Penglaitan section (Guangxi), the Xiaojiaba section (South China: Wang et al. 2004; Kaiho et al. 2005; Chen et al. 2011; Wei et al. 2012), and sections in Hungary and Greece (Wignall et al. 2012).

The causes of the biodiversity crisis and the large-scale perturbation of the carbon cycle 
55 have been crudely attributed to: global climate change (Isozaki et al. 2007a, 2007b; Clapham 56 et al. 2009; Nishikane et al. 2014), the major regression (Shen and Shi 2002; Leven 2003;

57 Yang et al. 2004; Wignall et al. 2009a), a massive extension of deep-water anoxia (Weidlich 58 2002; Clapham et al. 2009), catastrophic methane release (Retallack et al. 2006), and the 59 eruption of the Emeishan LIP (Ali et al. 2002; Wignall et al. 2009b). Nevertheless, the link 60 between the major regression and the mass extinction is frequently highlighted (e.g., Wang 61 and Jin 2000; Zhou et al. 2002; Wignall et al. 2009b), based primarily on sedimentary facies and carbon isotope evidence. Although some strontium isotopes have been mentioned in 63 previous studies, e.g., in the Laibin sections in South China (Wignall et al. 2009a), the 64 Abadeh section in central Iran (Liu et al. 2013), and the Boreal Realm (Spitsbergen) (Bond et al. 2015), the number of samples was too small to distinguish available causative events.

66 Regarding the biodiversity crisis, it appears that further ascertaining the inherent causes of the 67 negative carbon isotope excursion remains key.

In this study, two sections of marine carbonate strata from the Yangtze platform, South

69 China, are investigated in terms of major geological events and carbon-strontium isotope responses, which could further provide valuable clues regarding the causes of the biodiversity 71 crisis.

\section{Geologic setting}

The Yangtze carbonate platform in South China is bounded on the west by the Tibetan

75 Plateau, to the north by the Qinling-Dabie Orogen, and to the south by the Ailao Shan-Red 76 River Fault. Marine carbonate strata of the middle-late Permian, represented by the Maokou 
77 Formation, are widely developed around the Emeishan LIP, and occur frequently in the

78 Yunnan, Guizhou, Sichuan, and Guangxi provinces of South China (Fig. 1).

The Emeishan LIP outcrops in the western Yangtze Craton, the Southeast

Songpan-Gangze Terrane, and the East Tibet Block. The LIP consists of massive volcanic successions and numerous contemporaneous mafic and felsic intrusions, covering a rhombic-shaped area of $2.5 \times 10^{5} \mathrm{~km}^{2}$ and surrounded by several deep large faults, which include the Longmenshan-Anlinghe fault, the Ailao Shan-Red River slip fault, the Xiaojiang fault, and the Xichang-Qiaojia fault. The thickness of the erupted basalts ranges from several hundred meters to $5 \mathrm{~km}$ (Xu et al. 2001), and the original volume was substantially greater than $3.8 \times 10^{6} \mathrm{~km}^{3}$ (Xu et al. 2010). Volcanic eruptions in the early to middle stages showed a violent phreatomagmatic style and pyroclastic-phreatomagmatic volcanism. The depositional thicknesses of individual mafic volcaniclastic beds approaches $200 \mathrm{~m}$ (Wignall et al. 2009b). Remnant tuff layers of variable thickness (several to hundred meters) appear in the uppermost basalt successions (Bowring et al. 1998; Zhu et al. 2011). Dating using the zircon U-Pb isotopic method yields an approximate age of 262-259 Ma (He et al. 2007; Shellnutt et al. 2012; Zhong et al. 2014). However, it is difficult to accurately constrain the initial eruption time of the Emeishan basalts, because of the complicated contact relationships between the basalts and the Maokou carbonate strata (Emeishan flood basalts overlie Middle Permian carbonates and are, in turn, overlain by the latest Permian terrestrial or marine clastic rocks in the east and Triassic sedimentary rocks elsewhere, He et al. 2007). Wignall et al. (2009b),

97 placed the initial eruption and biodiversity crisis at the end of the Jinogondolella 98 xuanhanensis Zone in the late Guadalupian, based on conodont biostratigraphy in the 
99 Xiongjiachang section. Subsequently, Sun et al. (2010) moved the time of initial eruption of 100 the small-volume and very localized Emeishan basalts to $\sim 263 \mathrm{Ma}$ (around the 101 Jinogondolella altudaensis Zone), but the later, kilometer-scale eruptions with widespread 102 mafic and phreatomagmatic-style explosions were mainly assigned to the $J$. granti Zone (J.:

103
Jinogondolella).

According to He et al. (2003), the Emeishan LIP area is roughly divided into four zones: an intensely denuded zone (inner zone), a partially denuded zone (middle zone), a partial deposition zone (outer zone), and a continuous deposition zone. The sedimentary facies variations in the Yangtze platform are likely affected by the Emeishan LIP and Dongwu movement. The upper part of the Maokou Formation, which mainly consists of medium bedded to massive limestones, has a widespread unconformity with the Emeishan basalts in the west and center, and the Longtan Formation in the east (He et al. 2010).

Our study was limited to the top of the Maokou Formation. Two sections, Podu and Lengshuixi, are located in the outer zone of the LIP and in Qijiang and Shizhu counties, Chongqing city, South China, respectively.

The Podu section (upper Maokou Formation), which is $24 \mathrm{~m}$ thick, is divided into 15 beds and mainly consists of gray silt-fine crystal limestone with nodules and beds. The top of the Maokou Formation in this section is covered by $\sim 1 \mathrm{~m}$ thick mudstone (Fig. S1a) which contains some carbonate breccia at the bottom, and shows an unconformity with the Longtan Formation.

The Lengshuixi section (upper Maokou Formation), which has a thickness of $29 \mathrm{~m}$, is approximately $400 \mathrm{~km}$ from the Xiongjiachang section. The lithology contains gray thinly 
121 122 limestone is overlain by approximately $9 \mathrm{~m}$ thick shaly bed (Fig. S1b). The

\section{3}

124

125

126

127

bedded limestones and siliceous micrite divided into 38 beds. The uppermost part of the biostratigraphcally-defined G-L (Guadalupian-Lopingian) boundary is placed at bottom of the Wujiaping Formation (Isozaki et al. 2004; Sun et al. 2008).

\section{Sampling and methods}

\subsection{Sampling}

Eighty-seven samples were collected from two sections in the Sichuan Basin. At least one sample was collected from each thin bed, and three samples were collected from each thick bed. Sampling near veins related to late cracks was avoided if possible. For the $\mathrm{C}$ and $\mathrm{Sr}$ isotopes and conodont stratigraphy analyses, the mass of each sample was approximately 10 $\mathrm{kg}$.

\subsection{Analytical methods}

\subsubsection{Carbon isotope analysis}

The carbon isotope compositions were determined by the Isotopic Geochemistry Laboratory of the Chengdu University of Technology, Chengdu, China. Carbonate samples were extracted using a micro-drill, washed with deionized water, and dried. For each analysis, a $0.5-\mathrm{mg}$ sample was placed in a tube of the Gas-Bench automatic sampling system, cleaned with high-purity helium, and dissolved with $100 \% \mathrm{H}_{3} \mathrm{PO}_{4}$ at $70{ }^{\circ} \mathrm{C}$ for $2 \mathrm{~h}$. The $\delta^{13} \mathrm{C}$ value was measured using a Thermo Fisher Scientific MAT253 isotope mass spectrometer. Vienna Pee Dee Belemnite (VPDB) was used as a standard sample, and the test accuracy was 
$143 \pm 0.02 \%$.

3.2.2 Strontium isotope analysis

Geology and Exploitation of the Chengdu University of Technology, Chengdu, China. The samples $(50 \mathrm{mg})$, which were washed with deionized water and crushed to less than 0.0750 $\mathrm{mm}$, were dissolved using $1 \mathrm{M}$ ultrapure acetic acid for approximately $12 \mathrm{~h}$ on an electric hot plate at $60{ }^{\circ} \mathrm{C}$. A $1.5 \mathrm{~mL}$ pure solution was extracted after adding $1.5 \mathrm{~mL} 2.5 \mathrm{M} \mathrm{HCl}$. The $\mathrm{Sr}$ purification and separation of $\mathrm{Rb}$ and other cations such as $\mathrm{Ca}^{2+}$ and $\mathrm{Ba}^{2+}$ was performed using AG $50 \mathrm{~W} \times 12$ cation exchange resin. ${ }^{87} \mathrm{Sr} /{ }^{86} \mathrm{Sr}$ ratios were then measured using a Thermo

Fisher Scientific TRITON Plus Mass Spectrometer.

The measured ${ }^{87} \mathrm{Sr} /{ }^{86} \mathrm{Sr}$ ratios were normalized to a ${ }^{86} \mathrm{Sr} /{ }^{88} \mathrm{Sr}$ ratio of 0.1194 , and calculated from 150 measurements. An internal precision of $\sim 5 \times 10^{-6}$ (RSE) was maintained. The analytical precision was monitored using the NBS 987 standard. The mean measured value obtained for NBS 987 was $0.710247 \pm 0.000008(2 \sigma, n=6)$. All reported ${ }^{87} \mathrm{Sr} /{ }^{86} \mathrm{Sr}$ data were corrected to a nominal value of 0.710248 for NBS 987 .

\section{Results}

\subsection{Mn and Sr content}

To determine the effect of diagenesis, the $\mathrm{Mn}$ and $\mathrm{Sr}$ contents in all samples were tested using an ELAN DRC-e inductively coupled plasma mass spectrometer (PerkinElmer SCIEX) in the Isotopic Geochemistry Laboratory of the Chengdu University of Technology, Chengdu, 
165

166

167

168

China. According to previous research, samples with $\mathrm{Mn}$ (content) $<250 \mathrm{ppm}$ and $\mathrm{Sr}$ (content) $>400 \mathrm{ppm}$, or $\mathrm{Mn} / \mathrm{Sr}<0.625$, were classified as well preserved (Bruckschen et al. 1999; Korte et al. 2003, 2005). The analysis results showed that Mn contents ranged from 11 to $223 \mathrm{ppm}$, Sr contents ranged from 490 to $2604 \mathrm{ppm}$, and $\mathrm{Mn} / \mathrm{Sr}$ ratios were $<0.295$, indicating that effects due to diagenesis could be eliminated for all samples (Tables S1 and S2).

\subsection{Carbon and strontium isotopes}

All analytical results are shown in Tables S1 and S2 and Fig. 2. In the Podu section, the carbon and strontium isotopes varied from 0.88 to $4.40 \%$ o $\left(\delta^{13} \mathrm{C}_{\text {carb }}\right.$ values $)$ and 0.70689 to $0.70731\left({ }^{87} \mathrm{Sr} /{ }^{86} \mathrm{Sr}\right)$, respectively. During the early stage, negative $\mathrm{C}$ isotope excursions of $-\Delta 1.71 \%$, from $4.06 \%$ to $2.35 \%$, and a corresponding increase in ${ }^{87} \mathrm{Sr} /{ }^{86} \mathrm{Sr}$ values from 0.70702 to 0.70731 were observed in Beds 8 to 7 . The $\delta^{13} \mathrm{C}_{\text {carb }}$ values then declined slightly. The ${ }^{87} \mathrm{Sr} /{ }^{86} \mathrm{Sr}$ values tended to small increase from Beds 6 to 3. The $\mathrm{C}$ and $\mathrm{Sr}$ isotope compositions simultaneously increased until the bottom of Bed 1. Finally, an abrupt negative isotope excursion in $\mathrm{C}\left(-\Delta 3.52 \%\right.$ ) and a minimum ${ }^{87} \mathrm{Sr} /{ }^{86} \mathrm{Sr}$ (down to 0.70689 ) occurred below the Capitanian-Wuchiapingian boundary.

In the Lengshuixi section, the carbon and strontium isotopes varied from 0.01 to $3.05 \%$ $\left(\delta^{13} \mathrm{C}_{\text {carb }}\right.$ values) and 0.70689 to $0.70786\left({ }^{87} \mathrm{Sr} /{ }^{86} \mathrm{Sr}\right)$, respectively. The high $\mathrm{Sr}$ isotope values were very clear in the Lengshuixi section, but the variation in $\mathrm{C}$ isotopes was confined to a small range. The $\mathrm{C}$ isotope compositions in this section were probably disturbed and exhibited few fluctuations. Overall, the high ${ }^{87} \mathrm{Sr} /{ }^{86} \mathrm{Sr}$ values $(0.70786)$ with the negative $\mathrm{C}$ 
187 isotope excursions were still clear in Beds 26 to 23 (bottom), corresponding to Beds 8 to 7 in 188 the Podu section. At the top of the section, a negative excursion trend of $\mathrm{C}$ and $\mathrm{Sr}$ isotopes 189 was also seen (Fig. 2), but the variation was near that of the top of the Podu section. The 190 apparent relationship between the $\mathrm{C}$ and $\mathrm{Sr}$ isotope variations in the two sections requires 191 further analysis.

\subsection{Conodont stratigraphy}

Because the top of the Maokou Formation in the Yangtze Platform was mostly denuded, resulting in an uncertain sedimentary age, to obtain exact temporal constraints for the carbonate beds in the study sections for comparison with previous studies (regarding the 2012), this study employed high-resolution conodont stratigraphy. All samples were soaked in acetic acid solution for more than one month, and conodont samples were then picked postserrata and J. altudaensis (Fig. 2). dissolving by acetic acid. The residues contained typical magmatic or metamorphic mineral

\subsection{Continental materials in carbonate strata}

Residual-bearing terrigenous material were found in some carbonate samples after components, including mica, quartz, and other silicates (Fig. S2 and Table S3). These 
209 minerals, which had high ${ }^{87} \mathrm{Sr} /{ }^{86} \mathrm{Sr}$ values, were found in Bed 7 of the Podu section and in 210 Beds 23 and 21 of the Lengshuixi section, which may be associated with the regression event 211 in that interval.

\section{5. Discussion}

\subsection{Major geological events and carbon-strontium isotope responses}

215

\subsubsection{Early regression and isotope responses}

A large-scale regression event occurred in the early stage of the late Guadalupian, confirmed by previous studies (Wang and Jin 2000; Shen et al. 2007; Wignall et al. 2009a; Bond et al. 2010), and might have severely impacted the shallowest marine species and sedimentary environment throughout the Tethys. Wignall et al. (2009a) stated that a major regression record existed within the basinal succession of the Jiangnan Basin, based on a facies analysis of the Penglaitan and Tieqiao sections (GSSP), South China. They provided regional evidence of the shallowest water facies, which had sharp-based and hummocky cross-stratification beds related to storm activity. The peak regression, which is diagnostic of the end of low-stand deposition, occurred within the relatively shallow-water Laibin Limestone Member up to the top of Bed $5 b$ at the Penglaitan section, and Bed 5 at the Tieqiao section. The most likely timing of the mass extinction was probably associated with the regressive event at the beginning of the $J$. granti Zone (Wignall et al. 2009a). In the Podu section, the increasing $\mathrm{Sr}$ isotope ratios, from 0.70700 (top of Bed 10) to a maximum of 0.70731 (Bed 7), occurred in $J$. postserrata Zone. The regression likely began in Bed 10, and the peak occurred in Bed 7. Similarly, the increasing ${ }^{87} \mathrm{Sr} /{ }^{86} \mathrm{Sr}$ trend in the Lengshuixi section 
231

232

233

234 251 (the minimum in the study area), and $\delta^{13} \mathrm{C}$ decreased from $4.40 \%$ to $0.88 \%$ at the upper of 252 the carbonate, which likely corresponds to the negative carbon isotope excursion in the

simultaneously exists in Bed 27 to Bed 23. It is suggested that the Sr isotope ratio increase is a response to the regression event that results in a relative increase of continental $\mathrm{Sr}$ components in coeval sea water. The regression event, in terms of timing interval, was placed at the early stage of the late Guadalupian, slightly predating the shallow-water Laibin Limestone Member in the Penglaitan and Tieqiao sections. This regression probably spread over the Yangtze platform and the rest of the globe (Bond et al. 2015). The clear ${ }^{87} \mathrm{Sr} /{ }^{86} \mathrm{Sr}$ increase in sea water, as an indicator of the global regression, could be more dependable.

Our research also noted fluctuations in the Sr isotope values, and a few biological fossil relics (no intact biotic fossils) in the Lengshuixi section were found (Fig. 3B). This could be because there was clear dolomitization in the top of the Maokou Formation in the Lengshuixi section, or because late geological variations induced disturbances. Despite that, the evolutionary trend of $\mathrm{Sr}$ isotopes still indicated a clear correspondence with that of the Podu section (Fig. 2).

\subsubsection{Late volcanic eruptions and isotope responses}

The Emeishan LIP was an important geological event of the late Guadalupian in the study area. However, large-scale eruption of basalts mainly occurred after the regression event, as restricted by the conodont zone (J. altudaensis Zone), which strongly affected isotope records in the late Maokou carbonate strata. The $\mathrm{Sr}$ and $\mathrm{C}$ isotopes in the Podu section correspond with violent eruptions, i.e., ${ }^{87} \mathrm{Sr} /{ }^{86} \mathrm{Sr}$ decreased from 0.70714 to 0.70689 
253 Xiongjiachang and Gouchang sections, reported by Bond et al. (2010) (Fig. 2). The isotope 254 evolution in the Lengshuixi section also shows similar characteristics. The temporal overlap 255 between huge basalt eruptions and sudden isotope changes likely indicates an inherent 256 relationship. The decline in ${ }^{87} \mathrm{Sr} /{ }^{86} \mathrm{Sr}$ values implies that the $\mathrm{Sr}$ provenance in the seawater 257 carbonates is affected by $\mathrm{Sr}$ constituents from the mantle basalt reservoir. The $\delta^{13} \mathrm{C}_{\text {carb }}$ 258 fluctuations during the end-Guadalupian were probably not associated with bio-productivity 259 variations because $\delta^{13} \mathrm{C}_{\text {carb }}$ values after the early regression were consistently high and 260 (Wignall et al. 2009a; Bond et al. 2010).

\subsection{3 $\mathrm{CO}_{2}$ origin in volcanism and negative carbon isotope excursion}

It is not debatable that the volcanism released massive amounts of $\mathrm{CO}_{2}$. Explosive eruptions displaying a violent phreatomagmatic style spread spectacular pyroclastic-phreatomagmatic lava from the Emeishan LIP event across the western Yangtze platform. Some mafic volcaniclastic beds approached $200 \mathrm{~m}$ (Wignall et al. 2009b; Bond et al. 2010), and tuff layers of different thicknesses (several to hundreds of meters) appeared in the uppermost basalt successions (Bowring et al. 1998; Zhu et al. 2011). Based on estimates from

271 the Kilauea volcano, an eruption of $2 \times 10^{6} \mathrm{~km}^{3}$ of basalt could release $4 \times 10^{19} \mathrm{~g}$ of $\mathrm{CO}_{2}$ and 272 more than $10^{19} \mathrm{~g}$ of $\mathrm{SO}_{2}$. These $\mathrm{CO}_{2}$ emissions are approximately 15 times the current content 273 of the atmosphere (Gerlach and Graeber 1985: Kamo et al. 2003). Xu et al. (2010) considered 274 that the original volume of the Emeishan basalts was substantially greater than $3.8 \times 10^{6} \mathrm{~km}^{3}$. 
275 If this estimate is true, the LIP could also have provided a huge amount of $\mathrm{CO}_{2}$, equivalent to 276 that of the Kilauea volcano. Furthermore, volcanic events triggering widespread 277 metamorphism in the crust and assimilation (Marziano et al. 2008) can produce abundant $278 \mathrm{CO}_{2}$ (Ganino et al. 2008, 2009; Korte and Kozur 2010), 3.6-8.6 times larger than the mass of 279 magmatic $\mathrm{CO}_{2}$, according to a metamorphic aureole within the Emeishan LIP (Fig. 4) 280 (Ganino et al. 2008). Specifically, sediment-derived $\mathrm{CO}_{2}$ could release a gigantic amount of

$281{ }^{12} \mathrm{C}$-enriched $\mathrm{CO}_{2}$, due to significant organic matter splitting during volcanism, which would 282

severely impact the carbon cycle and lead to negative carbon isotope excursions in coeval marine carbonates.

Furthermore, we noted a clear difference in the carbon isotope fractionation between metamorphism (below $800^{\circ} \mathrm{C}$ ) and volcanic eruption (above $1200{ }^{\circ} \mathrm{C}$ ) in the $\mathrm{CO}_{2}$-carbonate fluid system. The calculated isotope equilibrium fractionation results indicated that the $\Delta_{\text {CO2-calcite }}$ value between metamorphism (below $800{ }^{\circ} \mathrm{C}$ ) and the duration of the volcanic eruption (over $1200{ }^{\circ} \mathrm{C}$ ) could have declined from $\sim 4.0 \%$ to a minimum value (Fig. 4) (Bottinga 1969; Chacko et al. 1991). If true, such isotope fractionation be a new factor causing negative excursions of carbon isotopes.

\subsection{Development processes of major geological events and biodiversity crisis}

The large-scale regression and volcanism in the late Guadalupian are two typical geological events that could have induced the associated biodiversity crisis. The early regression in the late Guadalupian was probably associated with Emeishan mantle plume emplacement (He et al. 2003, 2010) and Dongwu Uplift. Generally, the abrupt doming of the 
297 Earth's surface in the development stage of the mantle plume, marked by increasing ${ }^{87} \mathrm{Sr} /{ }^{86} \mathrm{Sr}$ 298 ratios in marine carbonates due to a relative increase of continent-derived $\mathrm{Sr}$ in coeval sea 299 water, led to land area broadening and large-scale losses of shallow water species habitats, 300 ultimately causing a decline in the number of shallow-water species containing tropical 301 invertebrate taxa. because of the LIP event, inducing large-scale metamorphism in the sedimentary strata or

\section{Conclusions}


The major conclusions of this study are shown in Fig. 5 and are detailed below.

(1) Two events occurred in the late Guadalupian. The early regression (in the $J$.

321 postserrata Zone), marked by high ${ }^{87} \mathrm{Sr} /{ }^{86} \mathrm{Sr}$ ratios, implies a predominant contribution from

322 terrigenous materials. The late, large-scale volcanic eruptions (beginning in the J. altudaensis

323 Zone) could have been an important cause of the abrupt and simultaneous decline in carbon

324 and strontium isotopes, which are attributed to the basaltic origin and large-scale release of

$325 \mathrm{CO}_{2}$ from the upper crust.

326 (2) The regression could have caused a wide-ranging loss of species habitat and a 327 consequent early biodiversity crisis in shallow water species assemblages. The volcanic 328 eruption, which released abundant $\mathrm{CO}_{2}$ and deleterious gases, was possibly a primary cause 329 of the crisis, which was further amplified from shallow water to the deep sea.

330 (3) The LIP creation process, which included metamorphism and volcanism, could have 331 produced abundant $\mathrm{CO}_{2}$ of meta-sedimentary origin that may have been released into the 332 atmosphere or ocean via abrupt eruption, impacting the carbon cycle, and leading to the 333 negative carbon isotope excursions. High-temperature isotope fractionation during volcanic processes could also be an important cause of the negative excursion of carbon isotopes.

\section{Acknowledgments}

This work was supported by the National Natural Science Foundation of China (Grant number 40739903). We sincerely thank Editor Ali Polat, the Associate Editor, and the anonymous reviewers for their detailed and valuable suggestions that greatly helped improve the manuscript. We also thank Prof. J.Y. Xu and Dr. D. Yang from the Chengdu University of 
341 Technology for carbon and strontium isotope analysis, Advanced Engineer P.Q. Kang from 342 Chengdu University of Technology for the field investigation, and Professor Z.H. Wang from 343 the Nanjing Institute of Geology and Palaeontology, Chinese Academy of Sciences, for 344 identification of the conodonts. We would like to thank Editage (www.editage.com) for 345 English language editing. All data are available in the supporting online material.

\section{References}

348

Ali, J.R., Thompson, G.M., Song, X.Y., and Wang, Y.L. 2002. Emeishan Basalts (SW China) and the ‘end-Guadalupian' crisis: magnetobiostratigraphic constraints. Journal of the Geological Society, 159: 21-29. doi:10.1144/0016-764901086.

Bond, D.P.G., Wignall, P.B., Wang, W., Izon, G., Jiang, H.S., Lai, X.L., Sun, Y.D., Newton, R.J., Shao, L.Y., Védrine, S., and Cope, H. 2010. The mid-Capitanian (Middle Permian) mass extinction and carbon isotope record of South China. Palaeogeography, Palaeoclimatology, Palaeoecology, 292: 282-294. doi: 10.1016/j.palaeo.2010.03.056.

Bond, D.P.G., Wignall, P.B., Joachimski M.M., Sun, Y., Savov, I., Grasby, S.E., Beauchamp, B., and Blomeier, D.P.G. 2015. An abrupt extinction in the Middle Permian (Capitanian) of the Boreal Realm (Spitsbergen) and its link to anoxia and acidification. Geological Society of America Bulletin, 127: 1411-1421. doi:10.1130/B31216.1.

Bottinga, Y. 1968. Calculation of fractionation factors for carbon and oxygen isotopic exchange in the system calcite-carbon dioxide-water. The Journal of Physical Chemistry, 72: 796-800. doi:10.1021/j100849a008.

Bottinga, Y. 1969. Calculated fractionation factors for carbon and hydrogen isotope exchange in the 
363

system calcite-carbon dioxide-graphite-methane-hydrogen-water vapor. Geochimica et Cosmochimica Acta, 33: 49-64. doi:10.1016/0016-7037(69)90092-1.

Bowring, S.A., Erwin, D.H., Jin, Y.G., Martin, M.W., Davidek, K., and Wang, W. 1998. U/Pb zircon geochronology and tempo of the end-Permian mass extinction. Science, 280: 1039-1045. doi:10.1126/science.280.5366.1039.

Bruckschena, P., Oesmanna, S., Veizerab, J. 1999. Isotope stratigraphy of the European carboniferous: proxy signals for ocean chemistry, climate and tectonics. Chemical Geology, 161: 127-163. doi:10.1016/S0009-2541(99)00084-4.

Chacko, T., Mayeda, T.K., Clayton, R.N., and Goldsmith, J.R. 1991. Oxygen and carbon isotope fractionations between $\mathrm{CO}_{2}$ and calcite. Geochimica et Cosmochimica Acta, 55: 2867-2882. doi:10.1016/0016-7037(91)90452-B.

Chen, B., Joachimski, M.M., Sun, Y.D., Shen, S.Z., and Lai, X.L. 2011. Carbon and conodont apatite oxygen isotope records of Guadalupian-Lopingian boundary sections: climatic or sea-level signal? Palaeogeography, Palaeoclimatology, Palaeoecology, 311: 145-153. doi:10.1016/j.palaeo.2011.08.016.

Christie-Blick, N. 2009. Volcanism: Eruptions and extinctions. Nature Geoscience, 2: 539-540. doi:10.1038/ngeo598.

Clapham, M.E., Shen, S.Z., and Bottjer, D.J. 2009. The double mass extinction revisited: reassessing the severity, selectivity, and causes of the end-Guadalupian biodic crisis (Late Permian). Paleobiology, 35: 32-50. doi:10.1666/08033.1.

Clarkson, M.O., Kasemann, S.A., Wood, R.A., Lenton, T.M., Daines, S.J., Richoz, S., Ohnemueller, F., Meixner, A., Poulton, S.W., and Tipper, E.T. 2015. Ocean acidification and the Permo-Triassic mass extinction. Science, 348: 229-232. doi:10.1126/science.aaa0193. 
385

386

Feng, Z.Z., Yang, Y.Q., Jin, Z.K., He, Y.B., Wu, S.H., Xin, W.J., Bao, Z.D., and Tan, J. 1996. Lithofacies Paleogeography of the Permian of South China. Acta Sedimentologica Sinica, 14: 1-11. doi:10.14027/j.cnki.cjxb.1996.02.001. [In Chinese with English Abstract.]

Ganino, C., Arndt, N.T., Zhou, M.F., Gaillard, F., and Chauvel, C. 2008. Interaction of magma with sedimentary wall rock and magnetite ore genesis in the Panzhihua mafic intrusion, SW China. Mineralium Deposita, 43: 677-694. doi:10.1007/s00126-008-0191-5.

Ganino, C., and Arndt, N.T. 2009. Climate changes caused by degassing of sediments during the emplacement of large igneous provinces. Geology, 37: 323-326. doi:10.1130/G25325A.1.

Gerlach, T.M., and Graeber, E.J. 1985. Volatile budget of Kilauea volcano. Nature, 313: 273-277. doi:10.1038/313273a0.

He, B., Xu, Y.G., Chung, S.L., Xiao, L., and Wang, Y.M. 2003. Sedimentary evidence for a rapid, kilometer-scale crustal doming prior to the eruption of the Emeishan flood basalts. Earth and Planetary Science Letters, 213: 391-405. doi:10.1016/S0012-821X(03)00323-6.

He, B., Xu, Y.G., Huang, X.L., Luo, Z.Y., Shi, Y.R., Yang, Q.J., and Yu, S.Y. 2007. Age and duration of the Emeishan flood volcanism, SW China: Geochemistry and SHRIMP zircon U-Pb dating of silicic ignimbrites, post-volcanic Xuanwei Formation and clay tuff at the Chaotian section. Earth and Planetary Science Letters, 255: 306-323. doi:10.1016/j.epsl.2006.12.021.

He, B., Xu, Y.G., Guan, J.P., and Zhong, Y.T. 2010. Paleokarst on the top of the Maokou Formation: Further evidence for domal crustal uplift prior to the Emeishan flood volcanism. Lithos, 119: 1-9. doi:10.1016/j.lithos.2010.07.019.

Isozaki, Y., Yao, J.X., Matsuda, T., Sakai, H., Ji, Z.S., Shimizu, N., Kobayashi, N., Kawahata, H., Nishi, H., Takano, M., and Kubo, T. 2004. Stratigraphy of the Middle-Upper Permian and Lowermost Triassic 
407 at Chaotian, Sichuan, China Record of Late Permian double mass extinction event. Proceedings of the 408 Japan Academy, Ser. B: Physical and Biological Sciences, 80: 10-16. doi:10.2183/pjab.80.10.

409 Isozaki, Y., Kawahata, H., and Ota, A. 2007a. A unique carbon isotope record across the 410 Guadalupian-Lopingian (Middle-Upper Permian) boundary in mid-oceanic paleo-atoll carbonates: The 411 high-productivity "Kamura event" and its collapse in Panthalassa. Global and Planetary Change, 55: $412 \quad$ 21-38. doi:10.1016/j.gloplacha.2006.06.006.

413 Isozaki, Y., Kawahata, H., and Minoshima, K. 2007b. The Capitanian (Permian) Kamura cooling event: 414 The beginning of the Paleozoic-Mesozoic transition. Palaeoworld, 16: 16-30. 415 doi:10.1016/j.palwor.2007.05.011.

416 Jin, Y.G., Shen, S.Z., Henderson, C.M., Wang, X.D., Wang, W., Wang, Y., Cao, C.Q., and Shang, Q.H. 417 2006. The Global Stratotype Section and Point (GSSP) for the boundary between the Capitanian and 418 Wuchiapingian Stage (Permian). Episodes, 29: 253-262.

419 Kaiho, K., Chen, Z.Q., Ohashi, T., Arinobu, T., Sawada, K., and Cramer, B.S. 2005. A negative carbon 420 isotope anomaly associated with the earliest Lopingian (Late Permian) mass extinction. 421 Palaeogeography, Palaeoclimatology, Palaeoecology, 223: 172-180. doi:10.1016/j.palaeo. 2005.04.013.

422 Kamo, S.L., Czamanske, G.K., Amelin, Y., Fedorenko, V.A., Davis, D.W., and Trofimov, V.R. 2003. 423 Rapid eruption of Siberian flood-volcanic rocks and evidence for coincidence with the Permian-Triassic 424 boundary and mass extinction at 251 Ma. Earth and Planetary Science Letters, 214: 75-91. 425 doi:10.1016/S0012-821X(03)00347-9.

426 Korte, C., Kozur, H.W., Bruckschen, P., and Veizer, J. 2003. Strontium isotope evolution of Late Permian 427 and Triassic seawater. Geochimica et Cosmochimica Acta, 67: 47-62. doi:10.1016/S0016-7037(02)01035-9. 
429 Korte, C., Jasper, T., Kozur, H.W., and Veizer, J. 2005. $\delta^{18} \mathrm{O}$ and $\delta^{13} \mathrm{C}$ of Permian brachiopods: A record 430 of seawater evolution and continental glaciation. Palaeogeography, Palaeoclimatology, Palaeoecology, 224: 333-351. doi:10.1016/j.palaeo.2005.03.015.

Korte, C. and Kozur H.W. 2010. Carbon-isotope stratigraphy across the Permian-Triassic boundary: A review. Journal of Asian Earth Sciences, 39: 215-235. doi:10.1016/j.jseaes.2010.01.005.

Leven, E.Y. 2003. Diversity dynamics of fusulinid genera and main stages of their evolution. Stratigraphy and Geological Correlation, 11: 220-230.

Liu, X.C., Wang, W., Shen, S.Z., Gorgij, M.N., Ye, F.C., Zhang, Y.C., Furuyama, S., Kano, A., and Chen, X.Z. 2013. Late Guadalupian to Lopingian (Permian) carbon and strontium isotopic chemostratigraphy in the Abadeh section, central Iran. Gondwana Research, 24: 222-232. doi:10.1016/j.gr.2012.10.012.

Marziano, I.G., Gaillard, F., and Pichavant, M. 2008. Limestone assimilation by basaltic magmas: An experimental re-assessment and application to Italian volcanoes. Contributions to Mineralogy and Petrology, 155: 719-738. doi:10.1007/s00410-007-0267-8.

Mei, S.L., Jin, Y.G., and Wardlaw, B.R. 1998. Conodont succession of the Guadalupian-Lopingian boundary strata in Laibin of Guangxi, China and West Texas, USA. Palaeoworld, 9: 53-76.

Nishikane, Y., Kaiho, K., Henderson, C.M., Takahashi, S., and Suzuki, N. 2014. Guadalupian-Lopingian conodont and carbon isotope stratigraphies of a deep chert sequence in Japan. Palaeogeography, Palaeoclimatology, Palaeoecology, 403: 16-29. doi:10.1016/j.palaeo.2014.02.033.

Retallack, G.J., Metzger, C.A., Greaver, T., Jahren, A.H., Smith, R.M.H., and Sheldon, N.D. 2006. Middle-Late Permian mass extinction on land. Geological Society of America Bulletin, 118: 1398-1411. doi:10.1130/B26011.1.

Shellnutt, J.G., Denyszyn S.W., and Mundil, R. 2012. Precise age determination of mafic and felsic 
451 intrusive rocks from the Permian Emeishan large igneous province (SW China). Gondwana Research,

452 22: 118-126. doi:10.1016/j.gr.2011.10.009.

453 Shen, S.Z., and Shi, G.R. 2002. Paleobiogeographical extinction patterns of Permian brachiopods in the Asian-western Pacific region. $\quad$ Paleobiology, 28: 463doi:10.1666/0094-8373(2002)028<0449:PEPOPB>2.0.CO;2.

Shen, S.Z., Wang, Y., Henderson, C.M., Cao, C.Q., and Wang, W. 2007. Biostratigraphy and lithofacies of 457 the Permian System in the Laibin-Heshan area of Guangxi, South China. Palaeoworld, 16: 120-139. doi:10.1016/j.palwor.2007.05.005.

Shen, S.Z., Cao, C.Q., Zhang, H., Bowring, S.A., Henderson, C.M., Payne, J.L., Davydov, V.I., Chen, B., Yuan, D.X., Zhang, Y.C., Wang, W., and Zheng, Q.F. 2013. High-resolution $\delta^{13} \mathrm{C}_{\text {carb }}$ chemostratigraphy from latest Guadalupian through earliest Triassic in South China and Iran. Earth and Planetary Science Letters, 375: 156-165. doi:10.1016/j.eps1.2013.05.020.

Shi, Z.J., Lu, L.X., Yin, G., Long, H.Y., Li, W.J., Yang, H.X., Cao, R., Tian, X.S., Tan, Q., Wang, K., Wang, Y., and Tian, Y.M. 2017. Remains of trilobites and other species discovered in a volcanic ash bed of the end-Permian, Yangtze craton, South China. International Geology Review, 59: 905-917. doi:10.1080/00206814.2016.1244777.

Sun, Y.D., Lai, X.L., Jiang, H.S., Luo, G.M., Sun, S., Yan, C.B., and Wignall, P.B. 2008. Guadalupian (Middle Permian) Conodont Faunas at Shangsi Section, Northeast Sichuan Province. Journal of China University of Geosciences, 19: 451-460. doi:10.1016/S1002-0705(08)60050-3.

Sun, Y.D., Lai, X.L., Wignall, P.B., Widdowson, M., Ali, J.R., Jiang, H.S., Wang, W., Yan, C.B., Bond D.P.G., and Védrine, S. 2010. Dating the onset and nature of the middle Permian Emeishan large igneous province eruptions in SW China using conodont biostratigraphy and its bearing on mantle 
473 plume uplift models. Lithos, 119: 20-33. doi:10.1016/j.lithos.2010.05.012.

474 Wang, Y., and Jin, Y.G. 2000. Permian palaeogeographic evolution of the Jiangnan Basin, South China.

475 Palaeogeography, Palaeoclimatology, Palaeoecology, 160: 35-44. doi:10.1016/S0031-0182(00)00043-2.

476 Wang, W., Cao, C.Q., and Wang, Y. 2004. The carbon isotope excursion on GSSP candidate section of 477 Lopingian-Guadalupian boundary. Earth and Planetaryence Letters, 220: 57-67. 478 doi:10.1016/S0012-821X(04)00033-0.

479 Wei, H.Y., Chen, D.Z., Yu, H., and Wang, J.G. 2012. End-Guadalupian mass extinction and negative 480 carbon isotope excursion at Xiaojiaba, Guangyuan, Sichuan. Science China Earth Sciences, 55: 481 1480-1488. doi:10.1007/s11430-012-4406-3.

Weidlich, O. 2002. Permian reefs re-examined: extrinsic control mechanisms of gradual and abrupt changes during 40 my of reef evolution. Geobios, 35: 287-294. doi:10.1016/S0016-6995(02)00066-9.

Wignall, P.B., Védrine, S., Bond, D.P.G., Wang, W., Lai, X.L., Ali, J.R., and Jiang, H.S. 2009a. Facies analysis and sea-level change at the Guadalupian-Lopingian Global Stratotype (Laibin, South China), and its bearing on the end-Guadalupian mass extinction. Journal of the Geological Society, 166: 655-666. doi:10.1144/0016-76492008-118.

Wignall, P.B., Sun, Y.D., Bond, D.P.G., Izon, G., Newton, R.J., Védrine, S., Widdowson, M., Ali, J.R., Lai, X.L., Jiang, H.S., Cope, H., and Bottrell, S.H. 2009b. Volcanism, Mass Extinction, and Carbon Isotope Fluctuations in the Middle Permian of China. Science, 324: 1179-1182. doi:10.1126/science.1171956.

Wignall, P.B., Bond, D.P.G.; Haas, J., Wang, W., Jiang, H.S., Lai, X.L., Altiner, D., Védrine, S., Hips, K., Zajzon, N., Sun, Y.D., and Newton, R.J. 2012. Capitanian (Middle Permian) mass extinction and recovery in western Tethys: a fossil, facies, and $\delta^{13} \mathrm{C}$ study from Hungary and Hydra island (Greece). 
Palaios, 27: 78-89. doi:10.2110/palo.2011.p11-058r.

496

497

498

Xu, Y.G., Chung, S.L., Jahn, B.M., and Wu, G.Y. 2001. Petrologic and geochemical constraints on the petrogenesis of Permian-Triassic Emeishan flood basalts in southwestern China. Lithos, 58: 145-168. doi:10.1016/S0024-4937(01)00055-X.

Xu, Y.G., Chung, S.L., Shao, H., and He, B. 2010. Silicic magmas from the Emeishan large igneous province, Southwest China: Petrogenesis and their link with the end-Guadalupian biological crisis. Lithos, 119: 47-60. doi:10.1016/j.lithos.2010.04.013.

Yang, X.N., Liu, J.R., and Shi, G.J. 2004. Extinction process and patterns of Middle Permian fusulinaceans in southwest China. Lethaia, 37: 139-147. doi:10.1080/00241160410005114.

Yang, Z., Yancey, T.E. 2000. Fusulinid biostratigraphy and paleontology of the Middle Permian (Guadalupian) strata of the Glass Mountains and Del Norte Mountains, West Texas. In The Guadalupian Symposium Smithsonian Contribution to the Earth Sciences Number 32. Edited by B.R. Wardlaw, R.E. Grant, and D.M. Rohr. Smithsonian Institution, Washington, DC. pp. 185-260.

Zhong, Y.T., He, B., Muntil, R., and Xu, Y.G. 2014. CA-Tims zircon U-Pb dating of felsic ignimbrite from the Binchuan section: implications for the termination age of Emeishan Large Igneous Province. Lithos, 204: 14-19. doi:10.1016/j.lithos.2014.03.005.

Zhou, M.F., Malpas, J., Song, X.Y., Robinson, P.T., Sun, M., Kennedy, A.K., Lesher, C.M., and Keays, R.R. 2002. A temporal link between the Emeishan large igneous province (SW China) and the end-Guadalupian mass extinction. Earth and Planetary Science Letters, 196: 113-122. doi:10.1016/S0012-821X(01)00608-2.

Zhu, J., Zhang, Z.C., Hu, T., and Kang, J.L. 2011. LA-ICP-MS zircon U-Pb geochronology of the tuffs on the uppermost of the Emeishan basalt succession in Panxian county, Guizhou province: constraints on 
517 genetic link between Emeishan large igneous province and the mass extinction. Acta Petrologica Sinica,

518 27: 2743-2751. [In Chinese with English Abstract.]

519 


\section{Figure captions}

521

522

Fig. 1. Distribution map of the Emeishan LIP, the location of geological sections, and paleogeography of South China (modified from Feng et al. 1996; Wang and Jin 2000). The distribution is divided into four zones: Inner Zone, Middle Zone, Outer Zone, and Continuous Deposition Zone (He et al. 2007; Shi et al. 2017). PD: Podu section (GPS: $\left.28^{\circ} 45^{\prime} 9^{\prime \prime} \mathrm{N}, 106^{\circ} 48^{\prime} 44^{\prime \prime} \mathrm{E}\right)$, LSX: Lengshuixi section (GPS: $29^{\circ} 54^{\prime} 0^{\prime \prime} \mathrm{N}$, 108 16'29"E), XJC: Xiongjiachang section, NY Basin: North Yangtze basin, WY Basin: West Yangtze basin, JN Basin: Jiangnan basin, LY Basin: Lower Yangtze basin.

Fig. 2. Geological column on Podu and Lengshuixi sections and isotope records in South China. (A) Geological column of the late Guadalupian in the Podu and Lengshuixi sections, including carbon-strontium isotope secular changes, lithology, beds, and conodont stratigraphy. (B) Composite isotope records in South China (after Bond et al. 2010), containing the Laibin (GSSP; Wang et al. 2004; Wignall et al. 2009a), Xiongjiachang, Houchang, and Gouchang sections (Bond et al. 2010). Fm.: Formation, Lith.: Lithology, Wu.: Wuchiapingian, Lo. F.: Longtan Formation, Wu. F.: Wujiaping Formation, GLB: biostratigraphically-defined Guadalupian-Lopingian Boundary, C.: Clarkina, J.: Jinogondolella.

Fig. 3. Photos of biological fossils from the late Maokou Formation, South China. Scale bar: $300 \mu \mathrm{m}$. (A) Conodonts in the Podu section. 1-2, 4-5, 9: Jinogondolella sp. from beds 2, 3, 4, and 7, respectively (upper views). 3: Jinogondolella altudaensis from bed 3, upper oblique view (3a) and upper views (3b). 6: ?Hindeodus sp. from bed 6, upper oblique view. 7-8: Jinogondolella postserrata (Behnken) from beds 6 and 7 , upper (7a, 7b, and 8b), and upper oblique views (8a), respectively. 10: Pseudohindeodus ramovsi Gullo and Kozur from bed 7, lateral view. (B) Some biological fossil debris found in the Lengshuixi 
541 section due to disturbance from clear dolomitization or late geological variations. Specimens 1-7 from bed 542 1, 8-9 from bed 4, 10-11 from bed 8, 12-13 from bed 11, and 17-18 from bed 14, respectively. All 543 specimens are displayed in lateral view.

544 Fig. 4. Modes for producing $\mathrm{CO}_{2}$ and other gases and the carbon isotope fractionation curve in different 545 stages of the LIP development process. The black bars (A to D) represent the relative amounts of $\mathrm{CO}_{2}, \mathrm{SO}_{2}$, 546 and $\mathrm{CH}_{4}$ released at various temperatures in the LIP development process, respectively. $\mathrm{D}\left(\sim 300{ }^{\circ} \mathrm{C}\right): \mathrm{CO}_{2}$ 547 from metamorphic degassing of organic carbon; C and B (approximately 500 to $700{ }^{\circ} \mathrm{C}$ ): decarbonation of 548 dolomite producing $\mathrm{CO}_{2}$; A $\left(\sim 900{ }^{\circ} \mathrm{C}\right)$ : desulfation of anhydrite; over $1200{ }^{\circ} \mathrm{C}: \mathrm{CO}_{2}$ from wall-rock 549 assimilation or the melting of carbonates produced during the near eruption stage (Ganino et al. 2008). 550 Carbon isotope fractionation curve after Bottinga $(1968,1969)$ and Chacko et al. (1991).

551 Fig. 5. Skeleton plot of the development processes behind major geological events and the biodiversity 552 crisis in the Late Guadalupian, South China. Intensity of the Emeishan LIP event is based on Sun et al. 553 (2010). Lop.: Lopingian, Wu.: Wuchiapingian, Con.: Conodont Zones, C. p. p.: Clarkina postbitteri 554 postbitteri, J. alt.: Jinogondolella altudaensis, J. post-shan.: Jinogondolella postserrata-shannoni. 


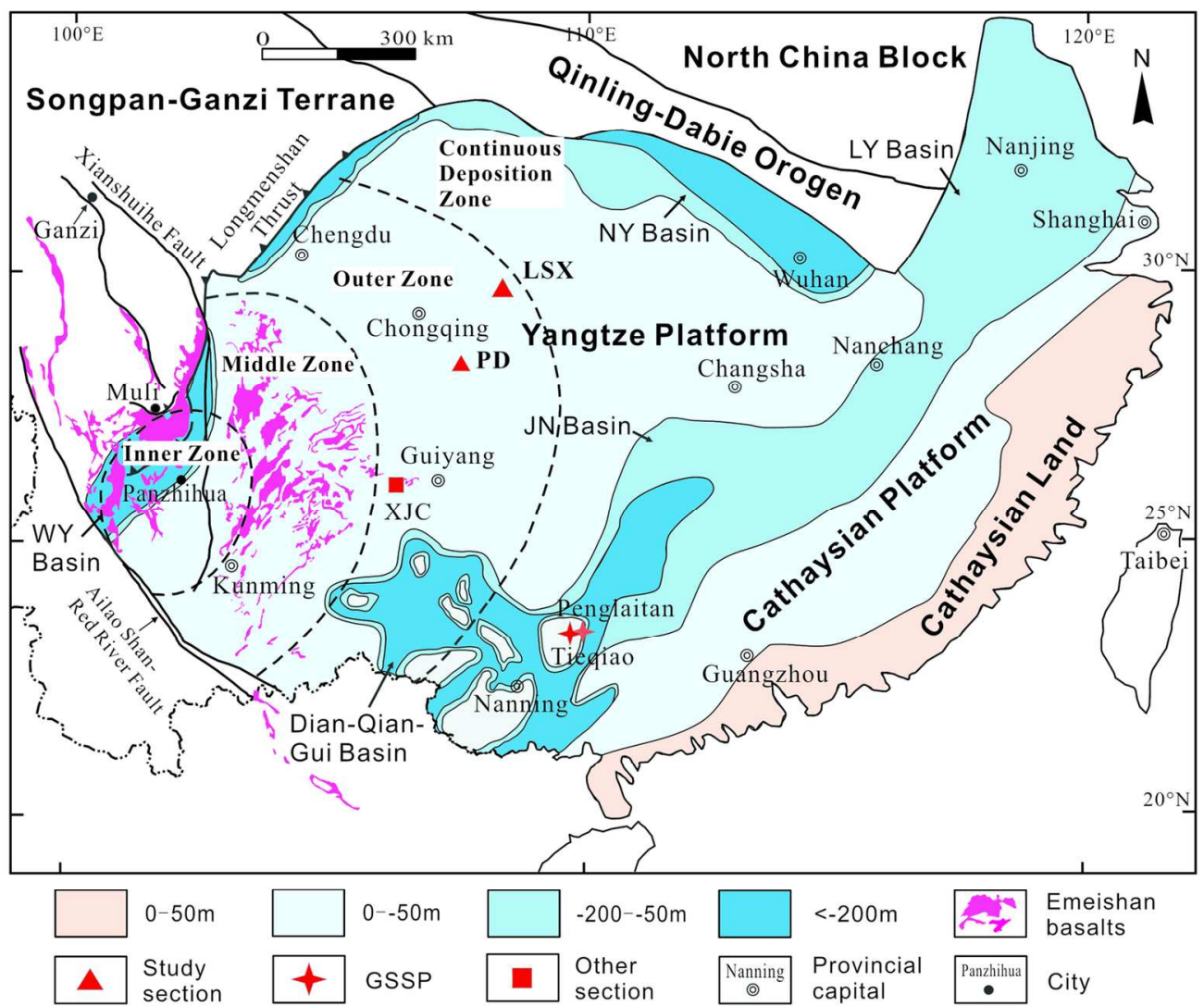

Fig. 1. Distribution map of the Emeishan LIP, the location of geological sections, and paleogeography of South China (modified from Feng et al. 1996; Wang and Jin 2000). The distribution is divided into four zones: Inner Zone, Middle Zone, Outer Zone, and Continuous Deposition Zone (He et al. 2007; Shi et al. 2017). PD: Podu section (GPS: $28^{\circ} 45^{\prime} 9^{\prime \prime N}, 106^{\circ} 48^{\prime} 44^{\prime \prime E}$ ), LSX: Lengshuixi section (GPS: $29^{\circ} 54^{\prime} 0^{\prime \prime N}$, $\left.108^{\circ} 16^{\prime} 29^{\prime \prime E}\right), \mathrm{XJC}$ : Xiongjiachang section, NY Basin: North Yangtze basin, WY Basin: West Yangtze basin, JN Basin: Jiangnan basin, LY Basin: Lower Yangtze basin.

$141 \times 118 \mathrm{~mm}(300 \times 300 \mathrm{DPI})$ 


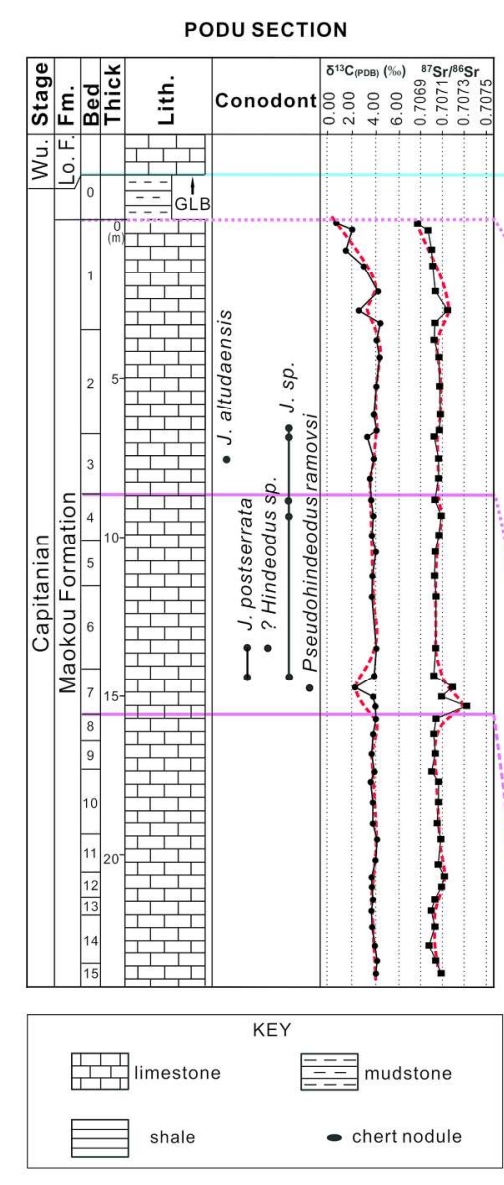

(A)
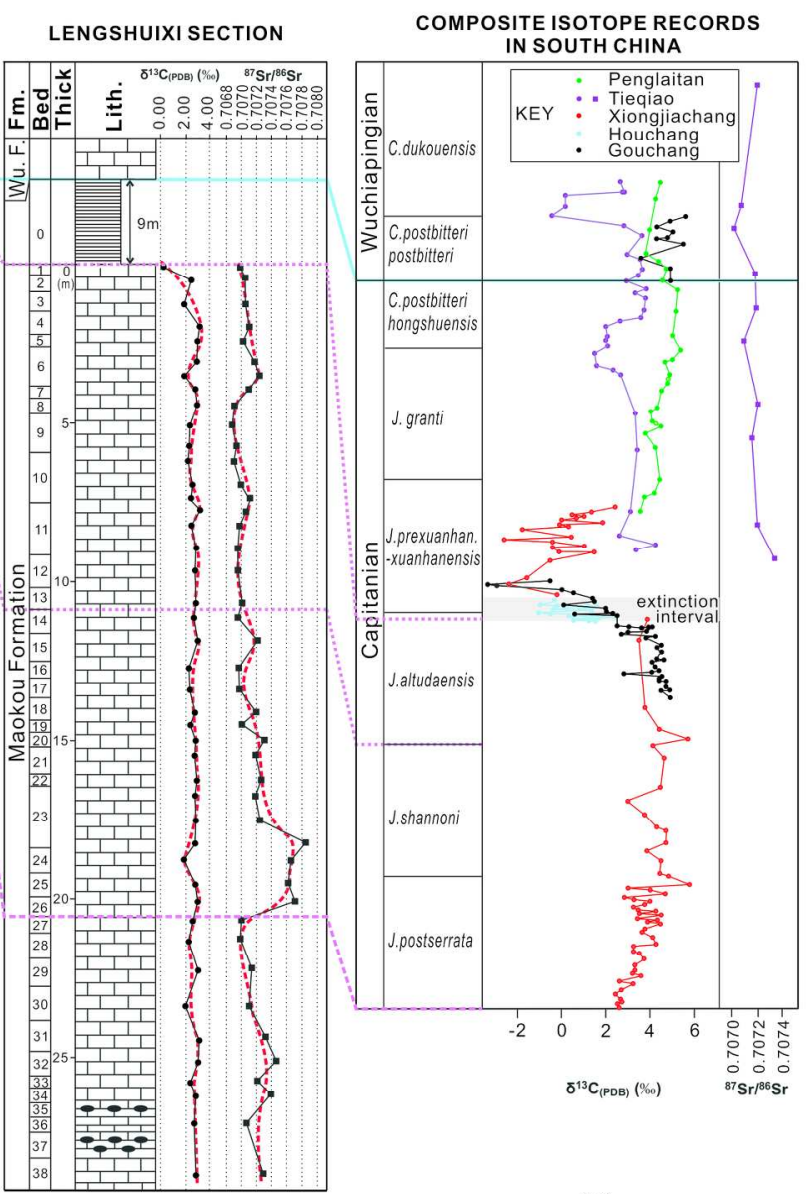

(B)

Fig. 2. Geological column on Podu and Lengshuixi sections and isotope records in South China. (A) Geological column of the late Guadalupian in the Podu and Lengshuixi sections, including carbon-strontium isotope secular changes, lithology, beds, and conodont stratigraphy. (B) Composite isotope records in South

China (after Bond et al. 2010), containing the Laibin (GSSP; Wang et al. 2004; Wignall et al. 2009a), Xiongjiachang, Houchang, and Gouchang sections (Bond et al. 2010). Fm.: Formation, Lith.: Lithology, Wu.: Wuchiapingian, Lo. F.: Longtan Formation, Wu. F.: Wujiaping Formation, GLB: biostratigraphically-defined Guadalupian-Lopingian Boundary, C.: Clarkina, J.: Jinogondolella.

$198 \times 185 \mathrm{~mm}(300 \times 300 \mathrm{DPI})$ 


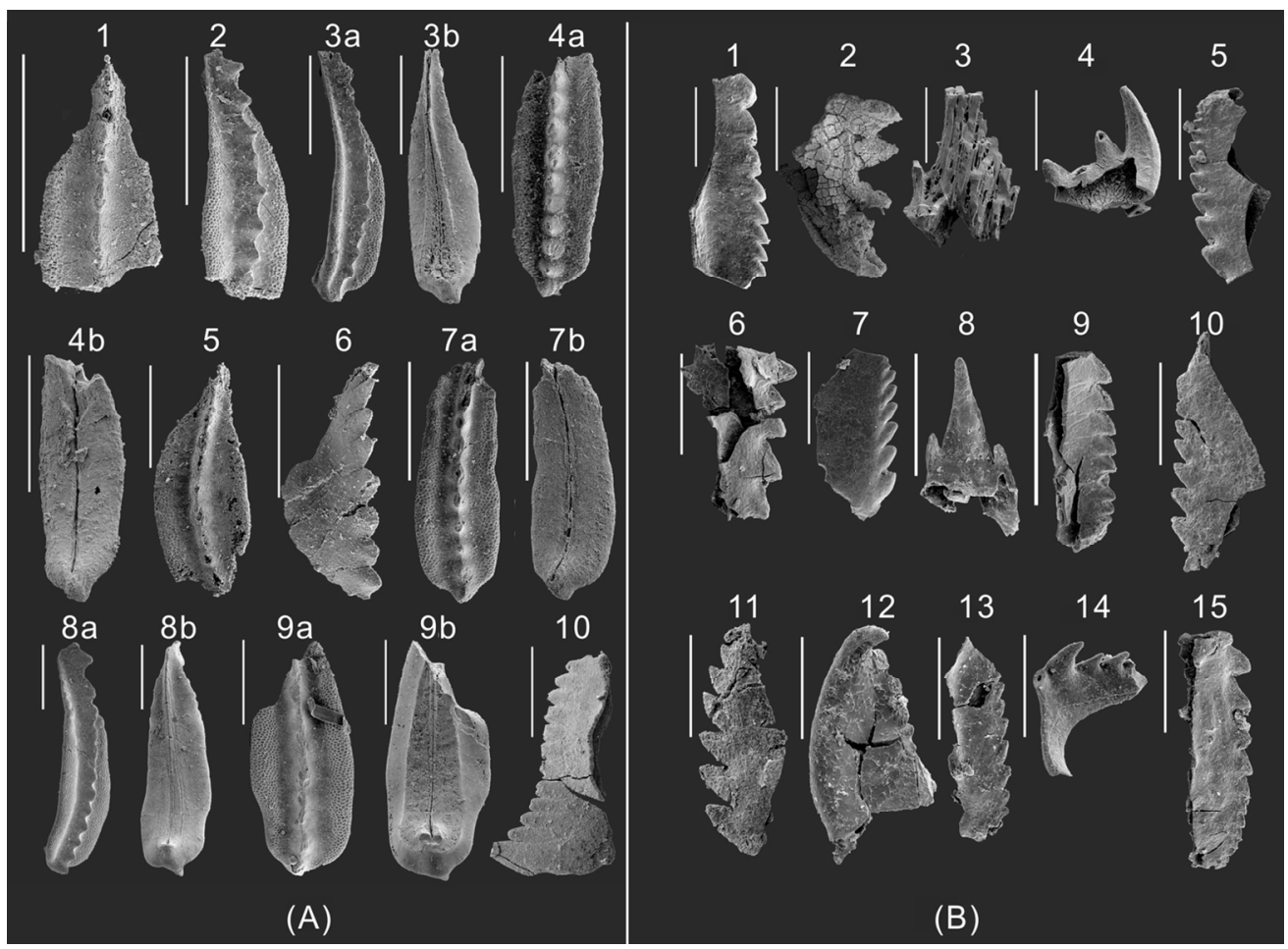

Fig. 3. Photos of biological fossils from the late Maokou Formation, South China. Scale bar: $300 \mu \mathrm{m}$. (A) Conodonts in the Podu Section. 1-2, 4-5, 9: Jinogondolella sp. from beds 2, 3, 4, and 7, respectively (upper views). 3: Jinogondolella altudaensis from bed 3, upper oblique view (3a) and upper views (3b). 6 : ?Hindeodus sp. from bed 6, upper oblique view. 7-8: Jinogondolella postserrata (Behnken) from beds 6 and 7, upper (7a, 7b, and 8b), and upper oblique views (8a), respectively. 10: Pseudohindeodus ramovsi Gullo and Kozur from bed 7, lateral view. (B) Some biological fossil debris found in the Lengshuixi Section due to disturbance from clear dolomitization or late geological variations. Specimens 1-7 from bed 1, 8-9 from bed 4, 10-11 from bed 8, 12-13 from bed 11, and 17-18 from bed 14, respectively. All specimens are displayed in lateral view.

$124 \times 90 \mathrm{~mm}(300 \times 300$ DPI $)$ 


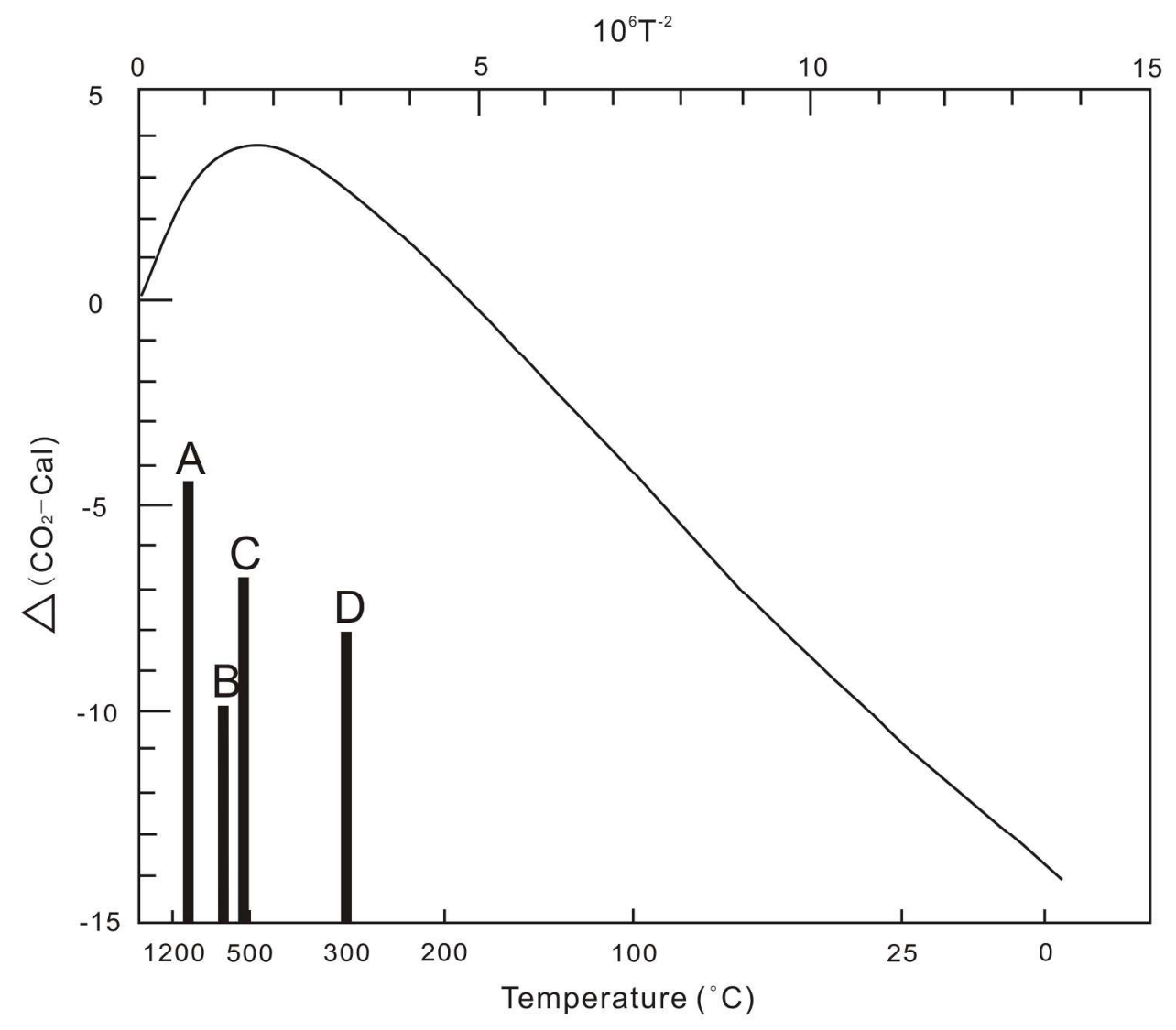

Fig. 4. Modes for producing $\mathrm{CO} 2$ and other gases and the carbon isotope fractionation curve in different stages of the LIP development process. The black bars (A to D) represent the relative amounts of $\mathrm{CO}_{2}, \mathrm{SO} 2$, and $\mathrm{CH} 4$ released at various temperatures in the LIP development process, respectively. $\mathrm{D}\left(\sim 300^{\circ} \mathrm{C}\right)$ : $\mathrm{CO} 2$ from metamorphic degassing of organic carbon; $\mathrm{C}$ and $\mathrm{B}$ (approximately 500 to $700^{\circ} \mathrm{C}$ ): decarbonation of dolomite producing CO2; A ( 900 $\left.{ }^{\circ} \mathrm{C}\right)$ : desulfation of anhydrite; over $1200^{\circ} \mathrm{C}$ : $\mathrm{CO} 2$ from wall-rock assimilation or the melting of carbonates produced during the near eruption stage (Ganino et al. 2008). Carbon isotope fractionation curve after Bottinga $(1968,1969)$ and Chacko et al. (1991).

$$
222 \times 200 \mathrm{~mm} \text { ( } 300 \times 300 \text { DPI) }
$$




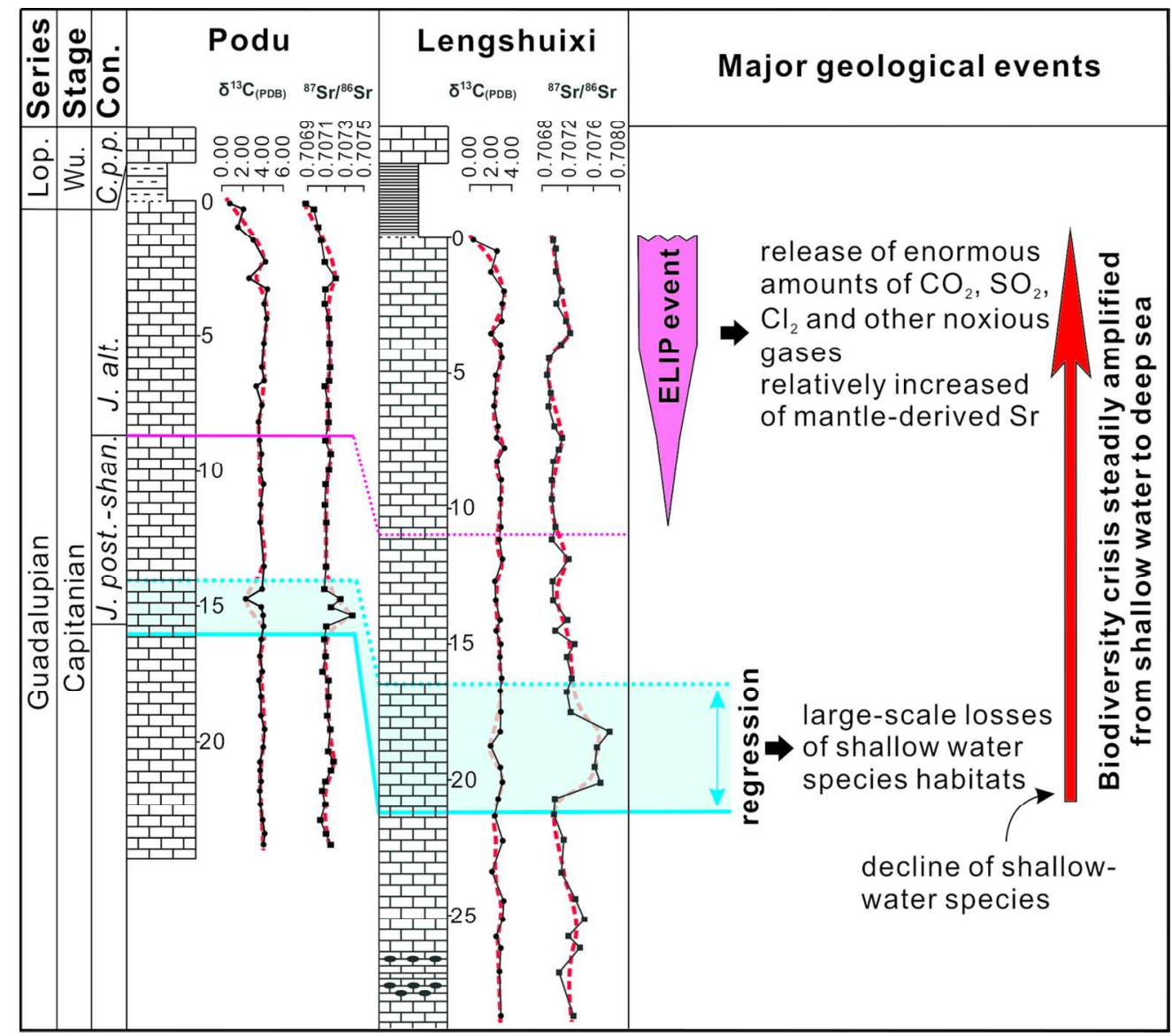

Fig. 5. Skeleton plot of the development processes behind major geological events and the biodiversity crisis in the Late Guadalupian, South China. Intensity of the Emeishan LIP event is based on Sun et al. (2010). Lop.: Lopingian, Wu.: Wuchiapingian, Con.: Conodont Zones, C. p. p.: Clarkina postbitteri postbitteri, J. alt.: Jinogondolella altudaensis, J. post-shan.: Jinogondolella postserrata-shannoni.

$$
127 \times 112 \mathrm{~mm}(300 \times 300 \mathrm{DPI})
$$




\section{Major geological events in the Late Guadalupian and carbon-strontium isotope responses in the Yangtze platform, South China}

Zejin Shi ${ }^{\mathrm{a}, \mathrm{b}, *}$, Guan Yin ${ }^{\mathrm{c}}$, Wenjie $\mathrm{Li}^{\mathrm{b}}$, Huaixin Yang ${ }^{\mathrm{b}}$, Jin Zhang ${ }^{\mathrm{b}}$, Leixun $\mathrm{Lu}^{\mathrm{b}}$, Yaming Tian ${ }^{c}$, Yong Wang ${ }^{c}$

${ }^{a}$ State Key Laboratory of Oil and Gas Reservoir Geology and Exploitation, Chengdu University of Technology, Chengdu 610059, China

${ }^{\mathrm{b}}$ College of Energy Resources, Chengdu University of Technology, Chengdu 610059, China

${ }^{c}$ College of Earth Sciences, Chengdu University of Technology, Chengdu 610059, China

*Corresponding author: Zejin Shi, E-mail: zejin_shi@hotmail.com 


\section{Supplementary Figures}
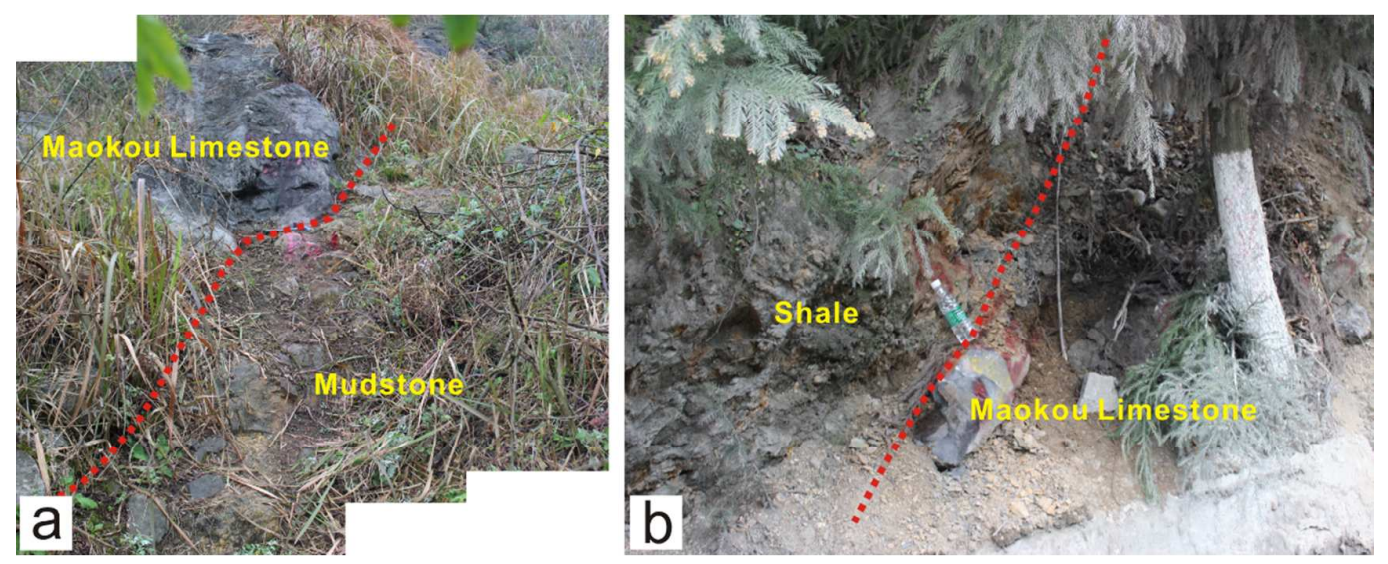

Figure S1. Photos of the stratigraphic boundary in the Podu section (a) and Lengshuixi section (b), South China. 

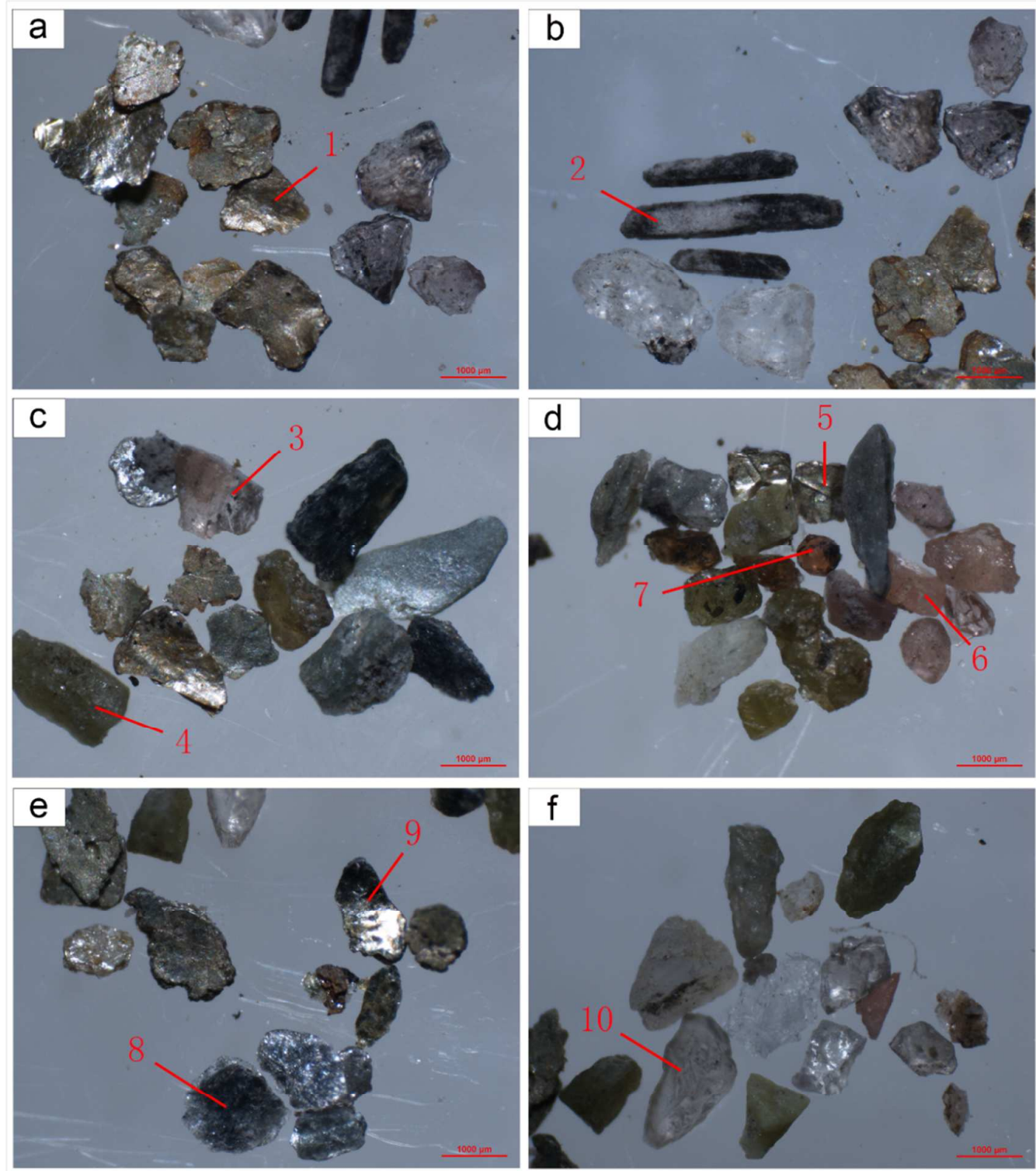

Figure S2. Residue-bearing terrigenous materials found in carbonate samples after dissolving by acetic acid. The residues contained some typical magmatic or metamorphic mineral components, including mica, quartz, and other silicates. a, b, and c: silicate minerals in Bed 7, Podu section; d: silicate minerals in Bed 21, e and f: silicate minerals in Bed 23, Lengshuixi section, South China. 1, 5, 8, and 9: mica; 2 and 10: quartz; 3: andalusite; 4: titanite; 6: feldspar; 7: garnet (interpreted). 


\section{Supplementary Tables}

Table S1. Isotope compositions and $\mathrm{Mn}$ and $\mathrm{Sr}$ contents of marine carbonate strata in the Podu section, South China.

\begin{tabular}{|c|c|c|c|c|c|c|}
\hline $\begin{array}{l}\text { Sample } \\
\text { number }\end{array}$ & $\begin{array}{c}\delta^{13} \mathrm{C} \\
(\%, \mathrm{PDB})\end{array}$ & ${ }^{87} \mathrm{Sr} /{ }^{86} \mathrm{Sr}$ & $2 \sigma$ & $\begin{array}{c}\text { Mn } \\
\text { (ppm) }\end{array}$ & $\begin{array}{c}\mathrm{Sr} \\
(\mathrm{ppm})\end{array}$ & $\mathrm{Mn} / \mathrm{Sr}$ \\
\hline NBS987 & & 0.71022 & $5.99 \mathrm{E}-06$ & & & \\
\hline NBS987 & & 0.71025 & 7.79E-06 & & & \\
\hline PD-1-1 & 0.88 & 0.70689 & $2.35 \mathrm{E}-05$ & 156 & 604 & 0.258 \\
\hline PD-1-2 & 2.08 & 0.70693 & $2.66 \mathrm{E}-05$ & 192 & 651 & 0.295 \\
\hline PD-1-3 & 1.60 & 0.70699 & $4.16 \mathrm{E}-05$ & 131 & 590 & 0.223 \\
\hline PD-1-4 & 3.05 & 0.70701 & $1.54 \mathrm{E}-05$ & 93 & 620 & 0.149 \\
\hline PD-1-5 & 4.21 & 0.70702 & $3.43 \mathrm{E}-05$ & 94 & 841 & 0.112 \\
\hline PD-1-6 & 2.69 & 0.70714 & $1.36 \mathrm{E}-05$ & 128 & 963 & 0.132 \\
\hline PD-1-7 & 4.40 & 0.70704 & $2.29 \mathrm{E}-05$ & 70 & 851 & 0.082 \\
\hline PD-2-1 & 4.08 & 0.70703 & $2.14 \mathrm{E}-05$ & 51 & 799 & 0.064 \\
\hline PD-2-2 & 4.34 & 0.70707 & $1.72 \mathrm{E}-05$ & 58 & 839 & 0.070 \\
\hline PD-2-3 & 4.08 & 0.70708 & $1.72 \mathrm{E}-05$ & 63 & 831 & 0.076 \\
\hline PD-2-4 & 3.88 & 0.70709 & $1.64 \mathrm{E}-05$ & 69 & 881 & 0.078 \\
\hline PD-2-5 & 4.08 & 0.70706 & $3.68 \mathrm{E}-05$ & 81 & 843 & 0.097 \\
\hline PD-3-1 & 3.35 & 0.70702 & $1.07 \mathrm{E}-05$ & 96 & 1097 & 0.088 \\
\hline PD-3-2 & 3.88 & 0.70706 & $2.31 \mathrm{E}-05$ & 76 & 963 & 0.079 \\
\hline PD-3-3 & 3.57 & 0.70707 & 4.19E-05 & 63 & 886 & 0.071 \\
\hline PD-4-1 & 3.66 & 0.70704 & $3.21 \mathrm{E}-05$ & 72 & 894 & 0.081 \\
\hline PD-4-2 & 3.82 & 0.70709 & $1.27 \mathrm{E}-05$ & 54 & 878 & 0.062 \\
\hline PD-4-3 & 3.71 & 0.70707 & $8.98 \mathrm{E}-06$ & 44 & 907 & 0.049 \\
\hline PD-5-1 & 4.01 & 0.70704 & $1.76 \mathrm{E}-05$ & 53 & 901 & 0.058 \\
\hline PD-5-2 & 3.78 & 0.70703 & $1.22 \mathrm{E}-05$ & 38 & 878 & 0.044 \\
\hline PD-6-1 & 3.73 & 0.70704 & $1.47 \mathrm{E}-05$ & 44 & 914 & 0.048 \\
\hline PD-6-2 & 4.06 & 0.70704 & $1.50 \mathrm{E}-05$ & 30 & 882 & 0.034 \\
\hline PD-7-1 & 3.93 & 0.70702 & $1.20 \mathrm{E}-05$ & 35 & 872 & 0.041 \\
\hline PD-7-2 & 2.35 & 0.70720 & $2.32 \mathrm{E}-05$ & 56 & 985 & 0.057 \\
\hline PD-7-3 & 3.83 & 0.70710 & $2.18 \mathrm{E}-05$ & 23 & 814 & 0.029 \\
\hline PD-7-4 & 4.00 & 0.70731 & $1.34 \mathrm{E}-05$ & 23 & 909 & 0.026 \\
\hline PD-8-1 & 4.06 & 0.70704 & $1.33 \mathrm{E}-05$ & 19 & 835 & 0.022 \\
\hline PD-8-2 & 3.83 & 0.70702 & $2.50 \mathrm{E}-05$ & 19 & 908 & 0.021 \\
\hline PD-9 & 3.70 & 0.70704 & $1.93 \mathrm{E}-05$ & 17 & 876 & 0.019 \\
\hline PD-10-1 & 3.92 & 0.70700 & $2.98 \mathrm{E}-05$ & 10 & 919 & 0.011 \\
\hline PD-10-2 & 3.62 & 0.70706 & $1.59 \mathrm{E}-05$ & 12 & 831 & 0.015 \\
\hline PD-10-3 & 3.79 & 0.70706 & $1.21 \mathrm{E}-05$ & 12 & 928 & 0.013 \\
\hline PD-10-4 & 3.79 & 0.70705 & $2.06 \mathrm{E}-05$ & 11 & 888 & 0.012 \\
\hline PD-11-1 & 4.13 & 0.70709 & $1.34 \mathrm{E}-05$ & 11 & 862 & 0.013 \\
\hline PD-11-2 & 4.00 & 0.70706 & $3.19 \mathrm{E}-05$ & 18 & 773 & 0.023 \\
\hline PD-12-1 & 3.75 & 0.70712 & 8.69E-06 & 14 & 869 & 0.016 \\
\hline PD-12-2 & 3.76 & 0.70710 & $2.09 \mathrm{E}-05$ & 14 & 847 & 0.016 \\
\hline PD-13-1 & 3.79 & 0.70703 & $1.30 \mathrm{E}-05$ & 16 & 884 & 0.018 \\
\hline PD-13-2 & 3.68 & 0.70700 & $1.96 \mathrm{E}-05$ & 14 & 1001 & 0.014 \\
\hline PD-14-1 & 3.71 & 0.70704 & $2.91 \mathrm{E}-05$ & 13 & 890 & 0.014 \\
\hline PD-14-2 & 3.96 & 0.70697 & $2.95 \mathrm{E}-05$ & 12 & 881 & 0.014 \\
\hline
\end{tabular}




\begin{tabular}{ccccccc} 
PD-14-3 & 4.13 & 0.70704 & $2.11 \mathrm{E}-05$ & 18 & 874 & 0.021 \\
PD-15 & 4.03 & 0.70709 & $1.54 \mathrm{E}-05$ & 14 & 956 & 0.015 \\
\hline
\end{tabular}

Table S2. Isotope compositions and $\mathrm{Mn}$ and $\mathrm{Sr}$ contents of marine carbonate strata in the Lengshuixi section, South China.

\begin{tabular}{|c|c|c|c|c|c|c|}
\hline $\begin{array}{l}\text { Sample } \\
\text { number }\end{array}$ & $\begin{array}{c}\delta^{13} \mathrm{C} \\
(\%, \mathrm{PDB})\end{array}$ & ${ }^{87} \mathrm{Sr} /{ }^{86} \mathrm{Sr}$ & $2 \sigma$ & $\begin{array}{c}\mathrm{Mn} \\
(\mathrm{ppm})\end{array}$ & $\begin{array}{c}\mathrm{Sr} \\
(\mathrm{ppm})\end{array}$ & $\mathrm{Mn} / \mathrm{Sr}$ \\
\hline NBS987 & & 0.71026 & $6.20 \mathrm{E}-06$ & & & \\
\hline NBS987 & & 0.71023 & $6.64 \mathrm{E}-06$ & & & \\
\hline NBS987 & & 0.71027 & $1.80 \mathrm{E}-05$ & & & \\
\hline NBS987 & & 0.71025 & $9.05 \mathrm{E}-06$ & & & \\
\hline LSX-1 & 0.01 & 0.70699 & $3.47 \mathrm{E}-05$ & 86 & 864 & 0.100 \\
\hline LSX-2 & 2.43 & 0.70703 & $1.35 \mathrm{E}-05$ & 65 & 1009 & 0.065 \\
\hline LSX-3 & 1.81 & 0.70704 & $3.76 \mathrm{E}-05$ & 54 & 585 & 0.092 \\
\hline LSX-4 & 3.05 & 0.70711 & $9.54 \mathrm{E}-06$ & 34 & 1031 & 0.033 \\
\hline LSX-5 & 2.82 & 0.70703 & $1.90 \mathrm{E}-05$ & 84 & 604 & 0.139 \\
\hline LSX-6-1 & 2.80 & 0.70718 & $1.26 \mathrm{E}-05$ & 31 & 1051 & 0.030 \\
\hline LSX-6-2 & 1.82 & 0.70725 & 4.46E-05 & 28 & 776 & 0.036 \\
\hline LSX-7 & 2.67 & 0.7071 & $1.08 \mathrm{E}-05$ & 15 & 747 & 0.020 \\
\hline LSX-8 & 2.81 & 0.70692 & $2.66 \mathrm{E}-05$ & 17 & 807 & 0.022 \\
\hline LSX-9-1 & 2.29 & 0.70689 & $9.65 \mathrm{E}-06$ & 26 & 2347 & 0.011 \\
\hline LSX-9-2 & 2.22 & 0.70695 & $1.45 \mathrm{E}-05$ & 36 & 939 & 0.038 \\
\hline LSX-10-1 & 2.12 & 0.70690 & $1.53 \mathrm{E}-05$ & 42 & 1340 & 0.031 \\
\hline LSX-10-2 & 2.49 & 0.70700 & $1.76 \mathrm{E}-05$ & 25 & 551 & 0.045 \\
\hline LSX-10-3 & 2.35 & 0.70712 & $4.26 \mathrm{E}-06$ & 22 & 744 & 0.030 \\
\hline LSX-11-1 & 3.04 & 0.70706 & $1.17 \mathrm{E}-05$ & 20 & 859 & 0.024 \\
\hline LSX-11-2 & 2.39 & 0.70699 & $2.47 \mathrm{E}-05$ & 28 & 637 & 0.044 \\
\hline LSX-11-3 & 2.79 & 0.70695 & $1.21 \mathrm{E}-05$ & 44 & 1254 & 0.035 \\
\hline LSX-12 & 2.77 & 0.70696 & $2.95 \mathrm{E}-05$ & 23 & 977 & 0.024 \\
\hline LSX-13 & 2.84 & 0.70703 & 2.07E-05 & 21 & 800 & 0.026 \\
\hline LSX-14 & 2.60 & 0.70693 & $1.71 \mathrm{E}-05$ & 23 & 675 & 0.035 \\
\hline LSX-15 & 3.01 & 0.70721 & $2.16 \mathrm{E}-05$ & 13 & 771 & 0.017 \\
\hline LSX-16 & 2.22 & 0.70696 & 2.29E-05 & 24 & 555 & 0.043 \\
\hline LSX-17 & 2.32 & 0.70698 & 4.17E-05 & 24 & 612 & 0.039 \\
\hline LSX-18 & 2.69 & 0.7072 & $1.47 \mathrm{E}-05$ & 35 & 490 & 0.071 \\
\hline LSX-19 & 2.34 & 0.70706 & $2.48 \mathrm{E}-05$ & 33 & 773 & 0.043 \\
\hline LSX-20 & 2.72 & 0.70731 & 2.97E-05 & 26 & 1110 & 0.023 \\
\hline LSX-21 & 2.61 & 0.70720 & $6.69 \mathrm{E}-05$ & 19 & 619 & 0.030 \\
\hline LSX-22 & 2.87 & 0.70727 & $2.45 \mathrm{E}-05$ & 29 & 594 & 0.048 \\
\hline LSX-23-1 & 2.63 & 0.70719 & $1.67 \mathrm{E}-05$ & 72 & 542 & 0.132 \\
\hline LSX-23-2 & 2.68 & 0.70725 & $9.24 \mathrm{E}-06$ & 43 & 1222 & 0.035 \\
\hline LSX-23-3 & 2.62 & 0.70786 & $1.57 \mathrm{E}-05$ & 33 & 1005 & 0.032 \\
\hline LSX-24 & 1.86 & 0.70765 & $1.29 \mathrm{E}-05$ & 66 & 731 & 0.091 \\
\hline LSX-25 & 2.64 & 0.70762 & $1.38 \mathrm{E}-05$ & 33 & 821 & 0.041 \\
\hline LSX-26 & 2.91 & 0.70772 & $2.98 \mathrm{E}-05$ & 26 & 931 & 0.028 \\
\hline LSX-27 & 2.52 & 0.70700 & $1.11 \mathrm{E}-05$ & 34 & 2604 & 0.013 \\
\hline
\end{tabular}




\begin{tabular}{llllccc} 
LSX-28 & 2.19 & 0.70699 & $5.32 \mathrm{E}-06$ & 223 & 996 & 0.224 \\
LSX-29 & 2.82 & 0.70715 & $2.50 \mathrm{E}-05$ & 43 & 2115 & 0.020 \\
LSX-30 & 1.92 & 0.70710 & $1.41 \mathrm{E}-05$ & 104 & 573 & 0.182 \\
LSX-31 & 3.03 & 0.70733 & $7.31 \mathrm{E}-06$ & 15 & 1170 & 0.013 \\
LSX-32 & 2.91 & 0.70746 & $9.67 \mathrm{E}-06$ & 35 & 1210 & 0.029 \\
LSX-33 & 2.33 & 0.70721 & $4.73 \mathrm{E}-05$ & 26 & 852 & 0.031 \\
LSX-34 & 2.72 & 0.70739 & $1.32 \mathrm{E}-05$ & 22 & 1247 & 0.017 \\
LSX-36 & 2.63 & 0.70708 & $1.35 \mathrm{E}-05$ & 35 & 2305 & 0.015 \\
LSX-38 & 2.78 & 0.70730 & $1.43 \mathrm{E}-05$ & 40 & 612 & 0.066 \\
\hline
\end{tabular}

Table S3. Electron probe analyses of representative minerals numbered in Figure S2.

\begin{tabular}{|c|c|c|c|c|c|c|c|c|c|c|}
\hline \multirow{2}{*}{$\begin{array}{l}\text { Sample } \\
\text { number }\end{array}$} & \multicolumn{8}{|c|}{ Chemical content in wt $\%$} & \multirow{2}{*}{$\begin{array}{l}\text { Sampling } \\
\text { location }\end{array}$} & \multirow{2}{*}{ Mineral } \\
\hline & $\mathrm{SiO}_{2}$ & $\mathrm{Al}_{2} \mathrm{O}_{3}$ & $\mathrm{FeO}$ & $\mathrm{K}_{2} \mathrm{O}$ & $\mathrm{CaO}$ & $\mathrm{MnO}$ & $\mathrm{TiO}_{2}$ & $\mathrm{MgO}$ & & \\
\hline 1 & 36.56 & 15.92 & 22.86 & 1.34 & 9.37 & - & 10.05 & 3.91 & PD-7 & Mica \\
\hline 2 & 98.70 & 0.24 & 1.04 & - & - & - & - & - & PD-7 & Quartz \\
\hline 3 & 49.20 & 50.80 & - & - & - & - & - & - & PD-7 & Andalusite \\
\hline 4 & 32.53 & 1.66 & - & - & 28.30 & - & 37.51 & - & PD-7 & Titanite \\
\hline 5 & 37.10 & 14.75 & 34.79 & 4.13 & 0.64 & 1.62 & 1.73 & 5.25 & LSX-21 & Mica \\
\hline 6 & 70.02 & 15.49 & - & 14.49 & - & - & - & - & $\mathrm{LSX}-21$ & Feldspar \\
\hline 7 & 35.38 & - & 33.45 & - & 1.58 & 29.60 & - & - & LSX-21 & Garnet (?) \\
\hline 8 & 58.93 & 28.45 & 4.68 & 6.03 & - & 1.91 & - & - & LSX-23 & Mica \\
\hline 9 & 42.21 & 13.69 & 27.23 & 4.64 & - & - & 1.97 & 10.26 & LSX-23 & Mica \\
\hline 10 & 100 & - & - & - & - & - & - & - & LSX-23 & Quartz \\
\hline
\end{tabular}

